\title{
Rapid recovery of normal gill morphology and blood physiology in brown trout (Salmo trutta) after short-term exposure to toxic concentrations of aqueous aluminium under non-steady state chemical conditions
}

\author{
Antonio Bjørn Stefano Poléo ${ }^{*}$, Birgitte Marie Kjelsberg ${ }^{2}$, Nina Alstad Rukke 3 , Leif Asbjørn Vøllestad ${ }^{4}$ \\ ${ }^{1}$ Inland Norway University of Applied Sciences, Campus Evenstad, P.O. Box 400, N-2418 Elverum; ${ }^{2}$ Norwegian Water Resources \\ and Energy Directorate, P.O. Box 5091 Majorstuen, N-0301 Oslo; ${ }^{3}$ Municipal Water Pollution Authority, P.O. Box 205, N-3401 \\ Lier; ${ }^{4}$ Center for Ecological and Evolutionary Synthesis, Department of Biosciences, University of Oslo, P.O. Box 1066 Blindern, N- \\ 0316 Oslo, Norway
}

\begin{abstract}
Freshwater acidification is characterised by elevated concentrations of aqueous aluminium. Global emissions of acidifying agents are reduced due to international agreements, and freshwater acidification has shifted from chronic to a more episodic character. The recovery of fish populations in acidified areas is likely to depend on the individual's ability to recover from short-time aluminium exposures. We exposed brown trout (Salmo trutta) to an Al-rich medium, nominal concentration $600 \mu \mathrm{g} \mathrm{L}^{-1}$, for $0.5,2,6,8$ and 11 hours, before transfer to circumneutral Al-poor water for recovery. As controls, fish were either exposed for 11 hours to an acidified Al-poor medium or to untreated water. Some mortality during the first 24 hours of the recovery period occurred in fish exposed for 11,8 and 6 hours to aluminium. No mortality during recovery was observed in the remaining groups. Aluminium exposure led to increased haematocrit and plasma lactate concentration, decreased plasma chloride concentration, deposition of aluminium on gill surfaces, and morphological alteration of the gill structures. The responses depended on exposure time. Aluminium deposited on the gill disappeared and plasma lactate levels were at control levels after 1 day in the recovery water, while haematocrit and plasma chloride levels were at control levels after 14 days of recovery. Gills in fish exposed to aluminium for 11 hours were almost fully recovered after 14 days. We conclude that the toxic response in brown trout exposed to an acutely toxic aluminium challenge is reversible. Moreover, the first 24 hours after aluminium exposures is the most critical period for the fish recovery. Further, it takes no more than 14 days for brown trout to fully recover from an acute toxic aluminium exposure, and only 1 day if the aluminium challenge is moderate.
\end{abstract}

\section{INTRODUCTION}

Acidification of soil water and freshwater systems have had extensive environmental impact throughout northern Europe, eastern USA and Canada (Harvey, 1975; Wright and Snekvik, 1978; Likens et al., 1979; Harriman and Morrison, 1981). The acidification was typically characterised by a chronic reduction of $\mathrm{pH}$ within the soil water systems with a subsequent mobilisation of both alu-

Corresponding author: antonio.poleo@inn.no

Key words: Aluminium toxicity; brown trout; Salmo trutta; freshwater acidification.

Edited by: Franz Hoelker, Leibniz Institute of Freshwater Ecology and Inland Fisheries, Berlin, Germany.

Received: 16 December 2020.

Accepted: 14 April 2021.

This work is licensed under a Creative Commons Attribution NonCommercial 4.0 License (CC BY-NC 4.0).

${ }^{\circ}$ Copyright: the Author(s), 2021

Licensee PAGEPress, Italy

J. Limnol., 2021; 80(2):2000

DOI: $10.4081 /$ jlimnol.2021.2000 minium $\left(\mathrm{Al}^{\mathrm{n}+}\right)$ and base cations $\left(\mathrm{Ca}^{2+}, \mathrm{Mg}^{2+}, \mathrm{Na}^{+}\right.$, and $\left.\mathrm{K}^{+}\right)$ from the edaphic to the aquatic environment (Cronan and Schofield, 1979; Seip et al., 1989; Lawrence et al., 1999; Stoddard et al., 1999), in addition to more short-term acidic episodes characterised by further decrease in the acid neutralising capacity (ANC) and extensively increased concentrations of aqueous aluminium, between 300 and $700 \mu \mathrm{g} \mathrm{L}^{-1}$ (Wigington et al., 1992, 1996; Wellington and Driscoll, 2004; Kowalik and Ormerod, 2006; Pye et al., 2012; Alexander et al., 2017). Acid episodes are often associated with snowmelt or triggered by sea-salt episodes in coastal areas following heavy rain and storm events (Skartveit and Gjessing, 1979; Johannesen et al., 1980; Hindar et al., 1994; Laudon and Bishop, 1999; Serrano et al., 2008). Regardless of the nature of the acidification, increased concentrations of aqueous aluminium in the runoff are considered to be one of the major environmental problems, and the relationship between aqueous aluminium and fish toxicity is well documented (Driscoll et al., 1980; Howells et al., 1994; Sparling and Lowe, 1996; Gensemer and Playle, 1999). Thus, one of the most serious effects was the decline or loss of natural fish populations in the affected areas (Schofield, 1976; Driscoll et al., 1980; Muniz and Leivestad, 1980a; Muniz, 1984).

Due to several natural measures and international agreements to reduce the emissions of sulphur and nitro- 
gen compounds, the acid deposition is reduced substantially since the early 1980s (Skjelkvåle et al., 1998, 2007; Garmo et al., 2008; Wright, 2008). Even though the biological recovery has lagged somewhat compared to the improvement of the water chemistry, several fish populations has started to recover from the acidification (Hesthagen et al., 2011, 2016; Enge et al., 2016). The reason for the mismatch between chemical and biological recovery, however, might be that ANC is still low in many affected areas, leading to a shift from chronic acidification towards more acid episodes (Wright, 2008), governed to a larger extent by naturally occurring organic acids (Fakhraei and Driscoll, 2015). Hence, the soil water systems are not constantly leaching aluminium anymore, but elevated amounts of aluminium are still mobilised during acid episodes due to the persistent reduced buffer capacity of the soil (low ANC). Consequently, in many areas fish are no longer chronically exposed to toxic levels of aluminium but face toxic episodes with elevated aqueous aluminium during snow melt in the spring or sea salt episodes during heavy rain and storm events (Laudon and Bishop, 1999; Serrano et al., 2008; Enge et al., 2016). This means that the survival and recovery of fish populations is dependent on the fish ability to withstand the duration of the acid episodes, and to recover from the possible damage imposed by the episodic exposure to elevated concentrations of aqueous aluminium. In a climate change perspective, the shift from chronic acidification towards acid episodes is highly relevant due to increased frequency and severity of storms, especially in coastal areas (Andersen, 2006).

Very often, the understanding of the effect of aluminium in natural waters and its interactions with aquatic biota is based largely upon chemical equilibrium constants. The environment, however, is never in steady state. Accordingly, true chemical equilibrium is seldom approached in natural systems (Fakhraei and Driscoll, 2015), especially not in the light of acid episodes (Hindar et al., 1994; Andersen, 2006). Thus, several ecotoxicological studies have demonstrated that a non-steady state aluminium chemistry can predominate (Weatherley et al., 1991; Rosseland et al., 1992; Lydersen et al., 1994; Poléo et al., 1994). These studies also indicate that a non-steady state transient aluminium chemistry, in which monomeric aluminium forms transform to polymeric aluminium forms, may dictate the aluminium toxicity in fish. When acidic aluminium rich soil water leaks into rivers and streams during acid episodes, aluminium solubility decreases as $\mathrm{pH}$ is elevated due to higher $\mathrm{pH}$ in the main water body, often leading to a transient increase in aluminium toxicity due to polymerisation and precipitation of aluminium onto the gill surfaces (Poléo, 1995; Poléo and Bjerkely, 2000). The main effects of aluminium exposure in fish are respiratory and ion regulatory distur- bances (Neville, 1985; Gensemer and Playle, 1999). Respiratory dysfunction seems to dominate at $\mathrm{pH}$ above 5.5 (Neville, 1985; Playle et al., 1989; Poléo and Bjerkely, 2000), where positively charged aluminium species bind to negatively charged sites at the gill surface (Poléo, 1995). Subsequent aluminium polymerisation and mucus secretion cause clogging of interlamellar spaces leading to hypoxia (Poléo, 1995; Poléo et al., 1995, 2017). Ion regulatory disturbances, however, predominates at $\mathrm{pH}$ below 4.5 and involves decreases in plasma $\mathrm{Na}^{+}$and $\mathrm{Cl}^{-1}$ (Neville, 1985; Gensemer and Playle, 1999).

The aim of the present study was to investigate to what degree brown trout (Salmo trutta) individuals can recover from episodic exposure to toxic levels of aqueous aluminium under non steady state conditions, and to describe a possible subsequent recovery process in more detail. It is still unclear what are the long-term effects of short-term exposures to toxic aluminium. We want to find out if short-term exposures to toxic levels of aluminium under non steady state conditions may lead to persistent morphological disruption of the gills and subsequent physiological effects in the fish or not. In this study, we investigate the effects of various short-term exposures to an acidic Al-rich medium under non steady state conditions on gill morphology and blood physiology in brown trout and evaluate if and how fast damages are repaired when the aluminium challenge is removed.

\section{METHODS}

\section{Experimental animals}

One-year old brown trout mean $( \pm$ sd) length $16.3 \pm 1.2$ $\mathrm{cm}$ and mean weight $42.5 \pm 10.5 \mathrm{~g}$, were obtained from a local hatchery near Oslo. The fish were brought into the fish-holding department at the University of Oslo, and kept in dechlorinated Oslo tap water (see Tab. 1 for details about water chemistry) at a flow through of water of $1 \mathrm{~L}$ $\mathrm{min}^{-1}$, for acclimation for two weeks before being introduced to the experimental set up. The dichlorination of the department water is performed by thiosulphate addition prior to entry into the fish holding unit of the department. The fish were not fed during acclimation and exposure periods to avoid interference with the chemical treatments and the blood physiological parameters. The fish were, however, fed ad libitum every 2-3 days during the subsequent recovery period to avoid starvation. All animal husbandry conditions and experimental protocols, including sampling procedures and experimental manipulations, reported in this paper were in strict accordance to the guidelines of the Norwegian Animal Research Authority, and approved by the head of the fish-holding department at the University of Oslo. Substantial efforts were made to minimize the number of fish used in the ex- 
periments, and to ensure humane endpoint for fish that were sacrificed for sampling.

\section{Test conditions and experimental protocol}

Our study consisted of two experiments; one preliminary toxicity test and one recovery experiment, both performed in the laboratory of the fish-holding department. The brown trout were exposed to an acidic Al-rich medium ( $\mathrm{pH}$ 5.8) for different time periods, and to an acidic Al-poor medium ( $\mathrm{pH}$ 5.6) as an acidic control and untreated department water $(\mathrm{pH}$ 6.4) as an overall control for 11 hours. A transient aluminium chemistry in the Al-rich medium was prepared by the addition of an $\mathrm{Al}$-stock solution $\left(\mathrm{Al}\left(\mathrm{NO}_{3}\right)_{3} \times 9 \mathrm{H}_{2} \mathrm{O}\right.$ dissolved in distilled water $\left(11 \mathrm{~g} \mathrm{~L}^{-1}\right)$ to the department water $(2.8 \mathrm{~mL}$ $\mathrm{min}^{-1}$ ) by means of a peristaltic pump Watson Marlow 205S. Due to the low $\mathrm{pH}$ in the Al-stock solution ( $\mathrm{pH} 2.6)$, the total amount of aluminium was present as $\mathrm{Al}^{3+}$. When the $\mathrm{pH}$ rapidly increased to 5.8 as the Al-stock solution was mixed with the department water, $\mathrm{Al}^{3+}$ start to polymerise into larger molecules (Hem and Roberson, 1967; Poléo, 1995; Poléo and Bjerkely, 2000). The nominal Al-concentration in the Al-rich medium was kept at $600 \mu \mathrm{g} \mathrm{L}^{-1}$ in all aluminium exposures. The acidic $\mathrm{Al}$-poor medium was made by adding a $\mathrm{HNO}_{3}$ solution to the department water, lowering the $\mathrm{pH}$ from 6.4 to 5.6. In order to minimise the effect of temperature on the aluminium chemistry, the water temperature was kept between 7.5 and $8.6^{\circ} \mathrm{C}$ during the experimental period.

We used a flow-through exposure system for the ex- periments (Fig. 1), that consisted of two exposure chambers $(28 \mathrm{~cm}$ long, $19 \mathrm{~cm}$ wide, and $10 \mathrm{~cm}$ deep). The water flow rate into each chamber was approximately 0.2 $\mathrm{L} \mathrm{min}^{-1}$, and the water residence time through the chambers was about $30 \mathrm{~min}$. We also used two flow-through channels for keeping the fish during the recovery period after the exposures (Fig. 1). Both channels were divided into 3 chambers, $43 \mathrm{~cm}$ long, $42 \mathrm{~cm}$ wide ad $14 \mathrm{~cm}$ deep. The fish were sheltered by covers over all chambers, and the water was well aerated on its way through the exposure chambers and the two channels.

In the preliminary toxicity test, we exposed a group of 40 brown trout to the Al-rich medium for 28 hours, until $100 \%$ mortality was achieved (Fig. 2). No mortality was observed in fish exposed to the untreated department water (control). Based on the results from this toxicity trial, i.e. the $\mathrm{LT}_{50}$ extrapolated from the mortality plot, which was approximately 12.5 hours, we decided the maximum exposure time to aluminium used in the recovery experiment to be 11 hours. The toxicity test was initiated as 40 fish were introduced to the exposure chambers, 20 in each. The addition of the Al-stock solution to the water entering the exposure chambers was started 6 hours before the test was started.

The recovery experiment consisted of 7 different exposures, each divided into an exposure period with a following recovery period for 42 days (Fig. 3). The 5 aluminium exposures were $0.5,2,6,8$ and 11 hours re-

Tab. 1. Water quality variables for the three different media used in the experiments. Only minimum and maximum values are given for $\mathrm{pH}$.

\begin{tabular}{|c|c|c|c|c|c|c|}
\hline \multirow[t]{2}{*}{ Water quality variable } & \multicolumn{2}{|c|}{ Al-rich medium } & \multicolumn{2}{|c|}{ Al-poor medium } & \multicolumn{2}{|c|}{ Untreated water } \\
\hline & n & mean \pm SD & n & mean & n & $\operatorname{mean} \pm \mathrm{SD}$ \\
\hline Temperature $\left({ }^{\circ} \mathrm{C}\right)$ & 10 & $8.1 \pm 0.5$ & 2 & 7.9 & 21 & $8.0 \pm 0.4$ \\
\hline Conductivity $\left(\mathrm{mS} \mathrm{cm}{ }^{-1}\right)$ & 10 & $22.8 \pm 0.1$ & 2 & 30.3 & 21 & $22.3 \pm 2.7$ \\
\hline $\mathrm{pH}$ & 10 & $5.7-5.8$ & 2 & 5.6 & 21 & $6.2-6.5$ \\
\hline $\mathrm{Na}^{+}\left(\mathrm{mg} \mathrm{L}^{-1}\right)$ & 6 & $1.66 \pm 0.04$ & 2 & 1.75 & 6 & $1.70 \pm 0.04$ \\
\hline $\mathrm{K}^{+}\left(\mathrm{mg} \mathrm{L}^{-1}\right)$ & 6 & $0.30 \pm 0.01$ & 2 & 0.30 & 6 & $0.30 \pm 0.01$ \\
\hline $\mathrm{Ca}^{2+}\left(\mathrm{mg} \mathrm{L}^{-1}\right)$ & 6 & $2.79 \pm 0.02$ & 2 & 2.81 & 6 & $2.78 \pm 0.04$ \\
\hline $\mathrm{Mg}^{2+}\left(\mathrm{mg} \mathrm{L}^{-1}\right)$ & 6 & $0.46 \pm 0.01$ & 2 & 0.45 & 6 & $0.46 \pm 0.01$ \\
\hline $\mathrm{F}^{\div}\left(\mu \mathrm{g} \mathrm{L}^{-1}\right)$ & 6 & $76.76 \pm 0.66$ & 2 & 73.14 & 6 & $78.00 \pm 1.40$ \\
\hline $\mathrm{Cl}^{*}\left(\mathrm{mg} \mathrm{L}^{-1}\right)$ & 6 & $2.60 \pm 0.04$ & 2 & 2.56 & 6 & $2.61 \pm 0.02$ \\
\hline $\mathrm{NO}_{3}^{*}\left(\mathrm{mg} \mathrm{L}^{-1}\right)$ & 6 & $4.40 \pm 0.02$ & 2 & 3.30 & 6 & $1.06 \pm 0.01$ \\
\hline $\mathrm{SO}_{4}{ }^{2 \div}\left(\mathrm{mg} \mathrm{L}^{-1}\right)$ & 6 & $4.93 \pm 0.01$ & 2 & 5.21 & 6 & $5.08 \pm 0.21$ \\
\hline $\begin{array}{l}\text { Alr }\left(\mu \mathrm{g} \mathrm{L}^{-1}\right) \\
\text { (total Al) }\end{array}$ & 10 & $608 \pm 52$ & 2 & 98 & 18 & $90 \pm 13$ \\
\hline $\begin{array}{l}\text { Ala }\left(\mu \mathrm{g} \mathrm{L}^{-1}\right) \\
\text { (total monomeric } \mathrm{Al})\end{array}$ & 10 & $458 \pm 46$ & 2 & 53 & 18 & $55 \pm 8$ \\
\hline $\begin{array}{l}\text { Alo }\left(\mu \mathrm{g} \mathrm{L}^{-1}\right) \\
\text { (organic monomeric } \mathrm{Al} \text { ) }\end{array}$ & 10 & $206 \pm 32$ & 2 & 38 & 18 & $42 \pm 4$ \\
\hline $\begin{array}{l}\text { Ali }\left(\mu \mathrm{g} \mathrm{L}^{-1}\right) \\
\text { (inorganic monomeric } \mathrm{Al} \text { ) }\end{array}$ & 10 & $252 \pm 50$ & 2 & 15 & 18 & $13 \pm 9$ \\
\hline
\end{tabular}


spectively in the acidic Al-rich medium. The 2 control exposures consisted of 11 hours in the acidic Al-poor medium and 11 hours in the untreated water. The addition of the Al-stock solution and the $\mathrm{HNO}_{3}$ solution to the water entering the exposure chambers was started 6 hours before the exposures started. Thus, each exposure, or trial, was initiated as the fish were introduced to the exposure chambers. In each exposure, we used 40 fish,

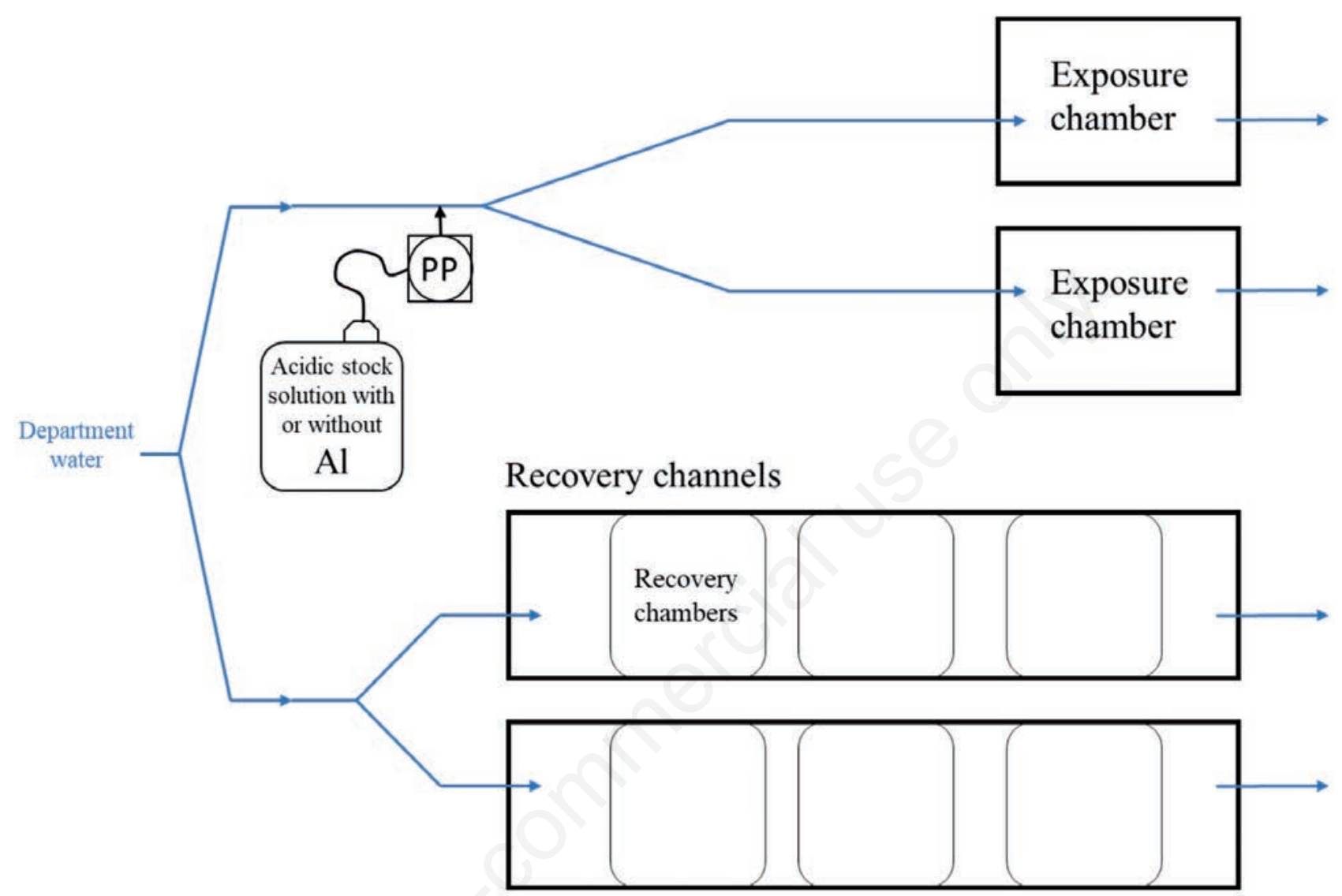

Fig. 1. Schematic presentation of the experimental set-up used in the experiments.

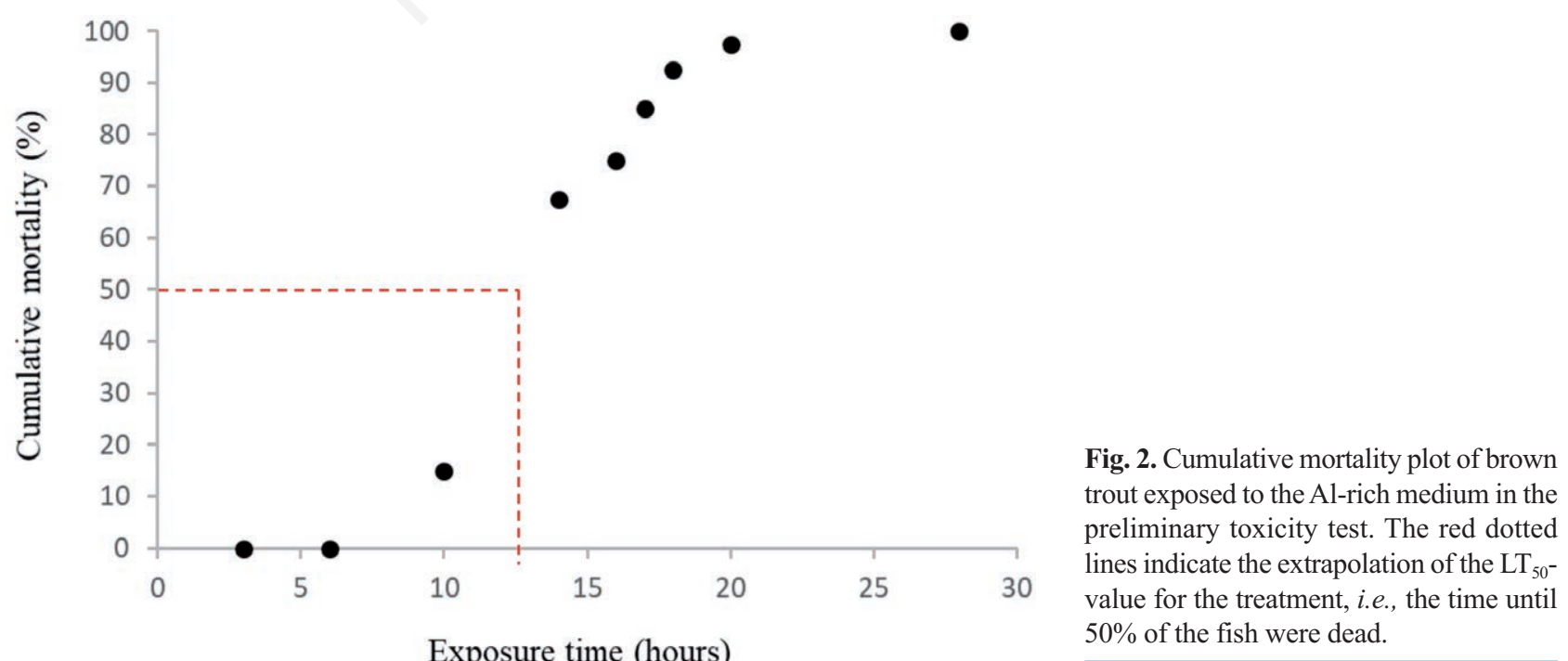


i.e., 20 in each chamber. The exposures were ended when the peristaltic pumps providing the chemicals to the water was turned off. Immediately after this, 10 individual fish were collected, 5 from each chamber, and euthanized with a firm blow to the head, to avoid any effects of anaesthetic drugs and time until fully anaesthetised on the physiological parameters. Subsequently, blood samples were collected by cardiac puncture, and transferred to $50 \mu 1$ blood caps and centrifuged for 5 minutes at $10000 \mathrm{rpm}$. Haematocrit was then measured before plasma was isolated and stored at $-80^{\circ} \mathrm{C}$ for later analysis of chloride and lactate concentrations. The apical gill arch on each side of the fish was dissected out for later analyses of surface structure by means of Scanning electron microscopy (SEM), and for staining and subsequent examination in light microscope. The gill arches for SEM were fixed and stored in a protein-fixating buffer $(3 \%$ glutaraldehyde and $1.5 \%$ paraformaldehyde in $0.1 \mathrm{M}$ cacodylate buffer; $\mathrm{pH}$ 7.4), while the gills for light microscopy was stored in a phosphate buffer containing paraformaldehyde. After the first sampling, the remaining fish were kept in the exposure chambers (15 in each) for 24 hours until the second sampling of 10 fish (5 from each chamber) was performed. The remaining fish, 20 in total, were transferred from the two exposure chambers into one of the chambers within the recovery channels, where they were kept for the rest of the recovery period before sampling after 14 and 42 days.

Water samples for chemical analyses from the various media in question were taken once during the exposures and once every week during the recovery period. The chemical dosage and water flow rate through the channels were controlled regularly prior to and during the exposures.

\section{Analytical techniques}

Water temperature and conductivity were measured directly by a mercury thermometer and a Radiometer CDM-80 conductivity meter respectively. The conductivity was determined when three consecutive measurements were identical within one tenth of a unit $\left(\mu \mathrm{S} \mathrm{cm}^{-1}\right)$. $\mathrm{pH}$ was measured using a Radiometer PHM- 80 with a Radiometer GK-2401C combined glass-electrode. Total fluoride $\left(\mathrm{F}^{*}\right)$ was analysed using an Orion Model 94-09 ion selective electrode, connected to an Orion Research Microprocessor Ion Analyser-901 with the Orion Model 9001-00 as reference electrode (Harwood, 1969). The precision of the ion selective fluoride electrode is expected to be $\pm 2 \%$ (Harwood, 1969). Water base cation content $\left(\mathrm{Na}^{+}, \mathrm{K}^{+}, \mathrm{Ca}^{2+}\right.$ and $\left.\mathrm{Mg}^{2+}\right)$ were analysed by Atomic Absorption Spectroscopy (AAS), $\mathrm{SO}_{4}{ }^{2+}, \mathrm{Cl}^{+}$by ion chromatography (IC), and $\mathrm{NO}_{3}{ }^{*}$ by the indophenol blue method. Aqueous aluminium was fractionated by the

\section{Type of exposure $\quad$ Exposure period}

Recovery period

$0.5 \mathrm{~h}$ to $\mathrm{Al}$-rich water

$2 \mathrm{~h}$ to $\mathrm{Al}$-rich water

$6 \mathrm{~h}$ to $\mathrm{Al}$-rich water

$8 \mathrm{~h}$ to $\mathrm{Al}$-rich water

$11 \mathrm{~h}$ to $\mathrm{Al}$-rich water

$11 \mathrm{~h}$ to $\mathrm{Al}$-poor water

$11 \mathrm{~h}$ to untreated water

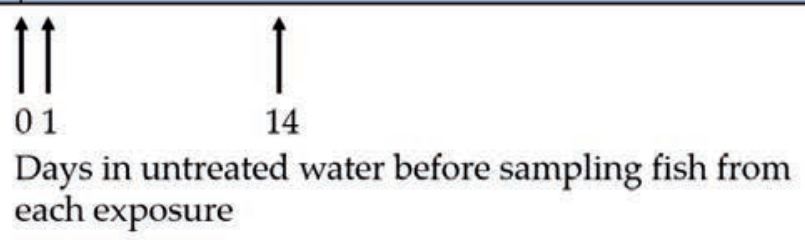

Fig. 3. Schematic presentation of the experimental protocol for the physiology experiment. Red bars indicate the acidic Al-rich medium, orange bar the Acidic Al-poor medium and blue bars the untreated water. 
HQ-MIBK extraction technique (Barnes, 1975), combined with a cation exchange procedure (Driscoll, 1984) according to a previously described protocol (Poléo et al., 1997). The operationally defined Al-fractions obtained are total aluminium (Alr), total monomeric aluminium (Ala), organic monomeric aluminium (Alo) and inorganic monomeric aluminium (Ali) (Barnes, 1975; Driscoll, 1984; Poléo et al., 1997).

Plasma chloride concentration was determined coulometrically using a Radiometer CMT-10 Chloride Titrator, with an expected precision of $\pm 0.5 \%$. Plasma lactate concentration was measured by an YSI Model 23L Lactate Analyzer. Whole gill arches for SEM were post fixed in $1 \% \mathrm{OsO}_{4}$, dehydrated in a graded series of ethanol, and critical point dried using $\mathrm{CO}_{2}$. Each gill arch was finally mounted on stubs using epoxy glue, sputter-coated with gold-palladium, and examined in a JEOL 6400 scanning electron microscope. Gills were scored on a scale of 0-3 for relative levels of gill damage; (0) no visible damage, (1) cell proliferation and clubbing of distal parts of filaments, (2) extensive clubbing and lamellar fusion, and (3) epithelial desquamation and general loss of gill structure, according to (Poléo and Bjerkely, 2000). Cross sections of gills for light microscopy were stained with $1 \%$ water soluble solochrome azurin at $\mathrm{pH} 5.0$ for detection of aluminium (Denton et al., 1984).

\section{Statistical analyses}

We tested for variation in the different blood physiology parameters using standard ANOVA. First, we tested for variation among treatment groups at the different time points. Then we tested for variation across time for each treatment group. The ANOVA was followed by a Tukey Kramer post hoc test to test for which groups or time points differed from which.

\section{RESULTS}

\section{Water chemistry}

There were only small differences in the concentration of different ions between treatments (Tab. 1). The main difference was the expected lowered $\mathrm{pH}$ in the acidic $\mathrm{Al}$ rich and Al-poor media (5.6-5.8) compared to the untreated department water (6.2-6.5), and the elevated concentration of $\mathrm{NO}_{3} \div(3.30-4.40 \mathrm{mg} \mathrm{L}-1)$ in the same to media, due to the addition of aluminium nitrate and nitric acid respectively, compared to the untreated water (1.06 $\mathrm{mg} \mathrm{L}^{-1}$ ). The water conductivity was somewhat higher in the acidic Al-poor medium $\left(30.3 \mu \mathrm{S} \mathrm{cm}^{-1}\right)$ compared to the acidic Al-rich medium and the untreated water (22.3$22.8 \mu \mathrm{S} \mathrm{cm}^{-1}$ ).

The total concentration of aluminium (Alr) in the department water was $90 \pm 13 \mu \mathrm{g} \mathrm{L}^{-1}$ throughout the study period, and both Alr and the subsequent aluminium fractions (Ala, Alo and Ali) in the acidic Al-poor medium corresponded well with those for the untreated department water (Tab. 1). In the Al-rich medium, however, the total Al-concentration was $608 \pm 52 \mu \mathrm{g} \mathrm{L}^{-1}$. The concentration of total monomeric aluminium (Ala) was $458 \pm 46 \mu \mathrm{g} \mathrm{L}^{-1}$, of organic monomeric aluminium (Alo) $206 \pm 32 \mu \mathrm{g} \mathrm{L}^{-1}$, and of inorganic monomeric aluminium (Ali) $252 \pm 50 \mu \mathrm{g}$ $\mathrm{L}^{-1}$ (Tab. 1).

\section{Fish mortality}

We observed some mortality in the recovery experiment. In the 11-hour exposure to the acidic Al-rich medium, 3 fish during the exposure, and 15 during the first 24 hours of recovery (Fig. 4). This mortality represented almost $50 \%$ of the fish in this exposure, which corresponded well with the $\mathrm{LT}_{50}$ of 12.5 hours from the

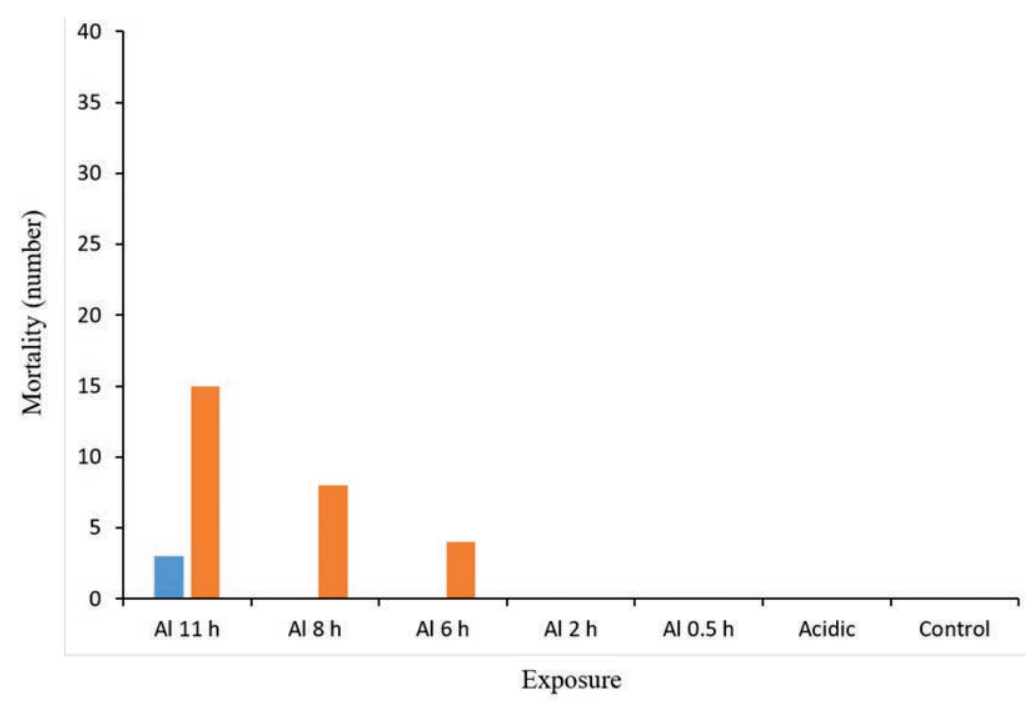

Fig. 4. Mortality of brown trout during the recovery experiment. Blue bars represent mortality during the Al-exposure, while red bars represent mortality during the first 24 hours of recovery in untreated department water. 
toxicity test. No mortality was observed during any of the other exposures, but fish exposed to the acidic Al-rich medium for 8 and 6 hours showed some mortality during the first 24 hours of recovery.

Fish exposed to the acidic Al-rich medium always responded by becoming inactive and started to ventilate the gills fast with irregular rhythms. Some individuals, in addition to those that died, lost their equilibrium but did not die.

\section{Blood and plasma parameters}

When the exposures to the acidic Al-rich medium were terminated, blood haematocrit levels were significantly elevated in the brown trout exposed to this medium for 2 hours and longer (42.4-68.0\%), compared to fish exposed to the acidic Al-rich medium for only 30 minutes, the acidic Al-poor medium and the untreated water (32.0 $37.6 \%$, Tab. 2). After 24 hours recovery in the department water, the fish exposed to the Al-rich medium for 11 and 8 hours still had significantly higher levels of blood haematocrit (41.8-49.9\%, Tab. 2). After 14 days of recovery, however, there were no statistically significant differences in blood haematocrit between any of the experimental groups, and haematocrit varied between 24.5 and $30.6 \%$. After 42 days of recovery, blood haematocrit was low in all groups (21.1-29.3\%), with some marginal differences among the groups (Tab. 2). For all the exposure groups, even the controls, there were statistically significant decreases in blood haematocrit through the recovery period (Tab. 2). We suspect that the somewhat el- evated haematocrit in the controls at the beginning of the recovery period was caused by an initial stress response in the fish when introduced to the experimental set up. Normal levels of blood haematocrit in salmonids in fresh water are reported to be within 20-35\% (McWilliams, 1980; Witters, 1986; Poléo and Bjerkely, 2000; Poléo and Hytterød, 2003).

Plasma chloride concentrations were significantly lower in the brown trout exposed to the acidic Al-rich medium for 6 hours and longer $\left(69.0-81.9 \mathrm{mmol} \mathrm{L}^{-1}\right)$, compared to fish exposed to the acidic Al-rich medium for 30 minutes or 2 hours, the acidic Al-poor medium and the untreated water (91.1-120.1 mmol L ${ }^{-1}$, Tab. 3). After 24 hours recovery in the department water, the fish exposed to the Al-rich medium for 11, 8 and 6 hours still had lower levels of plasma chloride (71.0-87.7 $\mathrm{mmol} \mathrm{L}^{-1}$, Tab. 3). After 14 days of recovery there were only minor differences in plasma chloride levels between all the experimental groups (110.4-125.0 $\mathrm{mmol} \mathrm{L}^{-1}$, Tab. 3). After 42 days of recovery the situation for plasma chloride levels was approximately the same (113.2-125.0 $\mathrm{mmol} \mathrm{L}^{-1}$, Tab. 3). For all the exposure groups, there was a statistically significant increase in plasma chloride concentration through the recovery period (Tab. 3). We also suspect that the somewhat lowered plasma chloride levels in the control at the beginning of the recovery period was caused by an initial stress response in the fish. Normal levels of plasma chloride in salmonids in fresh water are reported to be within $120-137 \mathrm{mmol} \mathrm{L}^{-1}$ (McWilliams, 1980; Witters, 1986; Poléo and Bjerkely, 2000; Poléo and Hytterød, 2003).

Plasma lactate concentrations were significantly

Tab. 2. Mean \pm SEM (n) blood haematocrit (\%) in brown trout at different times of recovery after exposure to acidic Al-rich water for five different time periods, and to acidic Al-poor water and untreated water as a control.

\begin{tabular}{|c|c|c|c|c|c|}
\hline \multicolumn{6}{|c|}{ Time of recovery (days) } \\
\hline Exposure (hours) & 0 & 1 & 14 & 42 & $\begin{array}{l}\text { F-statistic } \\
\text { (P-value) }\end{array}$ \\
\hline \multicolumn{6}{|l|}{ Al-rich medium } \\
\hline 11 & $67.2 \pm 12.1(5) \mathrm{a}$ & $41.4 \pm 2.1(6) \mathrm{ab}$ & $26.1 \pm 1.0(5) \mathrm{ba}$ & $25.8(2) b$ & $7.52(0.003)$ \\
\hline 8 & $48.2 \pm 1.9(10) \mathrm{abc}$ & $49.8 \pm 1.6(7) \mathrm{a}$ & $30.5 \pm 1.2(7) a b$ & $25.7 \pm 1.1(7) a b$ & $55.02(<0.001)$ \\
\hline 6 & $50.7 \pm 2.5(9) \mathrm{a}$ & $37.0 \pm 2.0(8) b$ & $27.4 \pm 1.3(9) \mathrm{ca}$ & $29.3 \pm 0.8(4) \mathrm{abc}$ & $30.86(<0.001)$ \\
\hline 2 & $42.8 \pm 1.1$ (9) abcd & $38.3 \pm 1.9(9) \mathrm{ab}$ & $26.6 \pm 2.3(7) \mathrm{ba}$ & $28.2 \pm 1.5(4) b$ & $18.53(<0.001)$ \\
\hline 0.5 & $32.0 \pm 0.9(10) \mathrm{b}$ & $38.4 \pm 1.2(10) \mathrm{a}$ & $28.6 \pm 1.6(5) b$ & $21.0 \pm 1.9(4) \mathrm{c}$ & $26.33(<0.001)$ \\
\hline \multicolumn{6}{|l|}{ Al-poor medium } \\
\hline 11 & $36.6 \pm 1.6(10) \mathrm{acd}$ & $34.8 \pm 1.5(10) \mathrm{ab}$ & $24.4 \pm 0.8(8) \mathrm{ba}$ & $27.0 \pm 2.1(6) \mathrm{ab}$ & $14.98(<0.001)$ \\
\hline \multicolumn{6}{|l|}{ Untreated water } \\
\hline 11 & $35.9 \pm 1.0(10)$ ad & $34.7 \pm 1.3(10) \mathrm{ab}$ & $27.4 \pm 2.0(9) \mathrm{ba}$ & $23.9 \pm 0.3(4) a b$ & $12.65(<0.001)$ \\
\hline F-statistic (P-value) & $13.14(<0.001)$ & $9.12(<0.001)$ & $1.44(0.223)$ & $2.84(0.031)$ & \\
\hline
\end{tabular}


higher in all brown trout exposed to the acidic Al-rich medium (3.47-7.58 $\mathrm{mmol} \mathrm{L}^{-1}$ ) compared to fish exposed to the acidic Al-poor medium and the untreated water (1.26-1.29 $\mathrm{mmol} \mathrm{L}^{-1}$, Tab. 4). After 24 hours recovery in the department water, no groups differed statistically significant in plasma lactate levels $\left(1.14-2.12 \mathrm{mmol} \mathrm{L}^{-1}, \mathrm{~F}\right.$ $=0.81, \mathrm{P}=0.567)$. After 14 days of recovery, plasma lac- tate levels were even lower $\left(0.49-1.04 \mathrm{mmol} \mathrm{L}^{-1}\right)$ and with some small but statistically significant difference among the experimental groups (Tab. 4). After 42 days of recovery plasma lactate levels were still low in all groups $\left(0.40-0.76 \mathrm{mmol} \mathrm{L}^{-1}, \mathrm{Tab} .4\right)$. For all the exposure groups, there was a statistically significant decrease in plasma lactate concentration through the recovery period (Tab. 4).

Tab. 3. Mean \pm SEM (n) plasma chloride concentration $\left(\mathrm{mmol} \mathrm{L}^{-1}\right)$ in brown trout at different times of recovery after exposure to acidic Al-rich water for five different time periods, and to acidic Al-poor water and untreated water as a control.

\begin{tabular}{|c|c|c|c|c|c|}
\hline \multicolumn{6}{|c|}{ Time of recovery (days) } \\
\hline Exposure (hours) & 0 & 1 & 14 & 42 & $\begin{array}{c}\text { F-statistic } \\
(P \text {-value })\end{array}$ \\
\hline \multicolumn{6}{|l|}{ Al-rich medium } \\
\hline 11 & $69.0 \pm 2.3(3) \mathrm{a}$ & $84.0 \pm 5.2(5) \mathrm{ab}$ & $123.9 \pm 2.0(5) \mathrm{ba}$ & $120.5(2) \mathrm{ab}$ & $43.90(<0.001)$ \\
\hline 8 & $76.9 \pm 2.7(10) \mathrm{a}$ & $71.0 \pm 3.0(7) \mathrm{ab}$ & $115.5 \pm 2.0(7) \mathrm{ba}$ & $123.2 \pm 1.2(7) \mathrm{ba}$ & $116.06(<0.001)$ \\
\hline 6 & $81.9 \pm 4.1(9) \mathrm{ab}$ & $87.7 \pm 4.6(8) a b$ & $123.6 \pm 2.5(9) \mathrm{ba}$ & $125.0 \pm 2.0(4) \mathrm{ba}$ & $34.65(<0.001)$ \\
\hline 2 & $101.7 \pm 2.2(9) \mathrm{ac}$ & $97.2 \pm 5.2(9) \mathrm{ab}$ & $110.4 \pm 5.0(7) \mathrm{ba}$ & $123.5 \pm 2.8(4) \mathrm{ba}$ & $5.38(0.005)$ \\
\hline 0.5 & $120.1 \pm 1.5(10) \mathrm{ad}$ & $95.4 \pm 3.0(10) \mathrm{ba}$ & $125.0 \pm 1.5(5) \mathrm{a}$ & $120.1 \pm 2.6(4) \mathrm{ab}$ & $33.98(<0.001)$ \\
\hline \multicolumn{6}{|l|}{ Al-poor medium } \\
\hline 11 & $91.1 \pm 2.4(10) \mathrm{abc}$ & $93.6 \pm 3.2(10) \mathrm{ab}$ & $123.3 \pm 1.1(8) \mathrm{ba}$ & $123.0 \pm 2.1(6) \mathrm{ba}$ & $49.80(<0.001)$ \\
\hline \multicolumn{6}{|l|}{ Untreated water } \\
\hline 11 & $101.5 \pm 2.1(10) a b c$ & $95.2 \pm 2.8(10) \mathrm{ba}$ & $113.7 \pm 6.5(8) \mathrm{a}$ & $113.2 \pm 2.4(5) \mathrm{ab}$ & $5.44(0.004)$ \\
\hline F-statistic (P-value) & $38.44(<0.001)$ & $5.29(<0.001)$ & $2.42(0.043)$ & $3.47(0.012)$ & \\
\hline
\end{tabular}

Results from one-way ANOVA with Tukey Kramer post-hoc tests. For each exposure group (within row), different letters denote significant different mean concentrations based on the Tukey Kramer HSD test, with overall statistic given in the last column ( $F$ and P-value). For each time period of recovery (within column), different letters denote significant different mean concentrations based on the Tukey Kramer HSD test, with overall statistic given in the last row ( $F$ and $P$-value). Statistically significant values in bold $(P<0.05)$.

Tab. 4. Mean \pm SEM (n) plasma lactate concentration $\left(\mathrm{mmol} \mathrm{L}^{-1}\right)$ in brown trout at different times of recovery after exposure to acidic Al-rich water for five different time periods, and to acidic Al-poor water and untreated water as a control.

\begin{tabular}{|c|c|c|c|c|c|}
\hline \multirow[b]{2}{*}{ Exposure (hours) } & \multicolumn{3}{|c|}{ Time of recovery (days) } & \multirow[b]{2}{*}{42} & \multirow[b]{2}{*}{$\begin{array}{c}\text { F-statistic } \\
(P \text {-value })\end{array}$} \\
\hline & 0 & 1 & 14 & & \\
\hline \multicolumn{6}{|l|}{ Al-rich medium } \\
\hline 11 & $6.18 \pm 1.38(3) \mathrm{abc}$ & $1.33 \pm 0.20(3) b$ & $0.98 \pm 0.30(3) \mathrm{ab}$ & $0.40 \pm(2) a b$ & $11.46(0.004)$ \\
\hline 8 & $6.16 \pm 0.84(6) a b c$ & $1.80 \pm 0.78(3) \mathrm{b}$ & $1.04 \pm 0.11(7) \mathrm{ab}$ & $0.44 \pm 0.08(7) b$ & $31.31(<0.001)$ \\
\hline 6 & $7.58 \pm 0.51(3) \mathrm{a}$ & $1.49 \pm 0.32(7) \mathrm{ba}$ & $1.05 \pm 0.15(9) \mathrm{ba}$ & $0.68 \pm 0.08$ (4) ba & $92.96(<0.001)$ \\
\hline 2 & $4.44 \pm 0.67(8) a b c$ & $2.12 \pm 0.84(5) \mathrm{aba}$ & $0.94 \pm 0.22(4) \mathrm{ab}$ & $0.76 \pm 0.19$ (4) ba & $7.48(0.002)$ \\
\hline 0.5 & $3.47 \pm 0.33(10) \mathrm{ac}$ & $1.66 \pm 0.17(10) \mathrm{ba}$ & $0.60 \pm 0.08(5) \mathrm{ab}$ & $0.52 \pm 0.20(3) \mathrm{ab}$ & $24.02(<0.001)$ \\
\hline \multicolumn{6}{|l|}{ Al-poor medium } \\
\hline 11 & $1.26 \pm 0.14(8) \mathrm{ad}$ & $1.47 \pm 0.15(8) \mathrm{a}$ & $0.49 \pm 0.04(7) \mathrm{b}$ & $0.57 \pm 0.13(5) \mathrm{ab}$ & $14.54(<0.001)$ \\
\hline \multicolumn{6}{|l|}{ Untreated water } \\
\hline 11 & $1.29 \pm 0.14(9) \mathrm{ad}$ & $1.14 \pm 0.08(8) \mathrm{ab}$ & $0.95 \pm 0.13(8) \mathrm{ab}$ & $0.57 \pm 0.09(3) \mathrm{ab}$ & $4.06(0.018)$ \\
\hline F-statistic (P-value) & $19.11(<0.001)$ & $0.81(0.567)$ & $2.78(0.025)$ & $0.90(0.512)$ & \\
\hline
\end{tabular}

Results from one-way ANOVA with Tukey Kramer post-hoc tests. For each exposure group (within row), different letters denote significant different mean concentrations based on the Tukey Kramer HSD test, with overall statistic given in the last column ( $F$ and P-value). For each time period of recovery (within column), different letters denote significant different mean concentrations based on the Tukey Kramer HSD test, with overall statistic given in the last row (F and P-value). Statistically significant values in bold $(P<0.05)$. 
For the controls, we suspect that this decrease could be caused by recovery from an initial stress response in the fish, but all values are within $0.50-1.50 \mathrm{mmol} \mathrm{L}^{-1}$ reported to be normal levels of plasma lactate in salmonids in fresh water (Witters, 1986; Poléo and Bjerkely, 2000).

\section{Gill morphology and aluminium deposition}

SEM micrographs of gills taken from brown trout right after the exposure to the acidic Al-rich medium showed that the gill epithelium was damaged, and that the degree of damage was dependent on the exposure time to aluminium (Fig. 5). Gills from fish exposed to the acidic Al-poor medium and the untreated department water did not show any signs of damage (damage class 0 ). Gills from fish exposed for 11 hours to aluminium were extensively damaged and scored to damage class 3 . Secondary lamellae showed a high degree of clubbing and lamellar fusion, the typical microridge pattern on the surface of the gill epithelial cells were absent, and the gill surfaces were covered by large amounts of debris - probably mucus and damaged cell fragments (Fig. 5F). Fish exposed for 6 and 8 hours to aluminium showed the same symptoms, but to a lesser degree, and hence scored to damage class 2. Clubbing and fusion of secondary lamellae was present, but not extensive, and the typical microridge pattern of the gill surface was evident several places. These gills as well, were covered by large amounts of debris. Gills from fish exposed to aluminium for 0.5 and 2 hours were scored to damage class 1 . Clubbing was evident, but fusion of the secondary lamella could only be seen a few places, and the micro ridge pattern of the gill surfaces was almost intact. No debris was observed on these gills (Fig. 5B-C).

For the recovery, only SEM micrographs from fish exposed to aluminium for 11 hours were examined. Already after a recovery period of 24 hours in the untreated water, no debris was present on the gill surfaces and the micro ridge pattern had returned and was evident on the major part of the gill surfaces (Fig. 6A). Secondary lamellae, however, were still fused and there was still evidence of extensive clubbing, so we scored the gills to damage class 2. After 14 days of recovery, the micro ridge pattern was
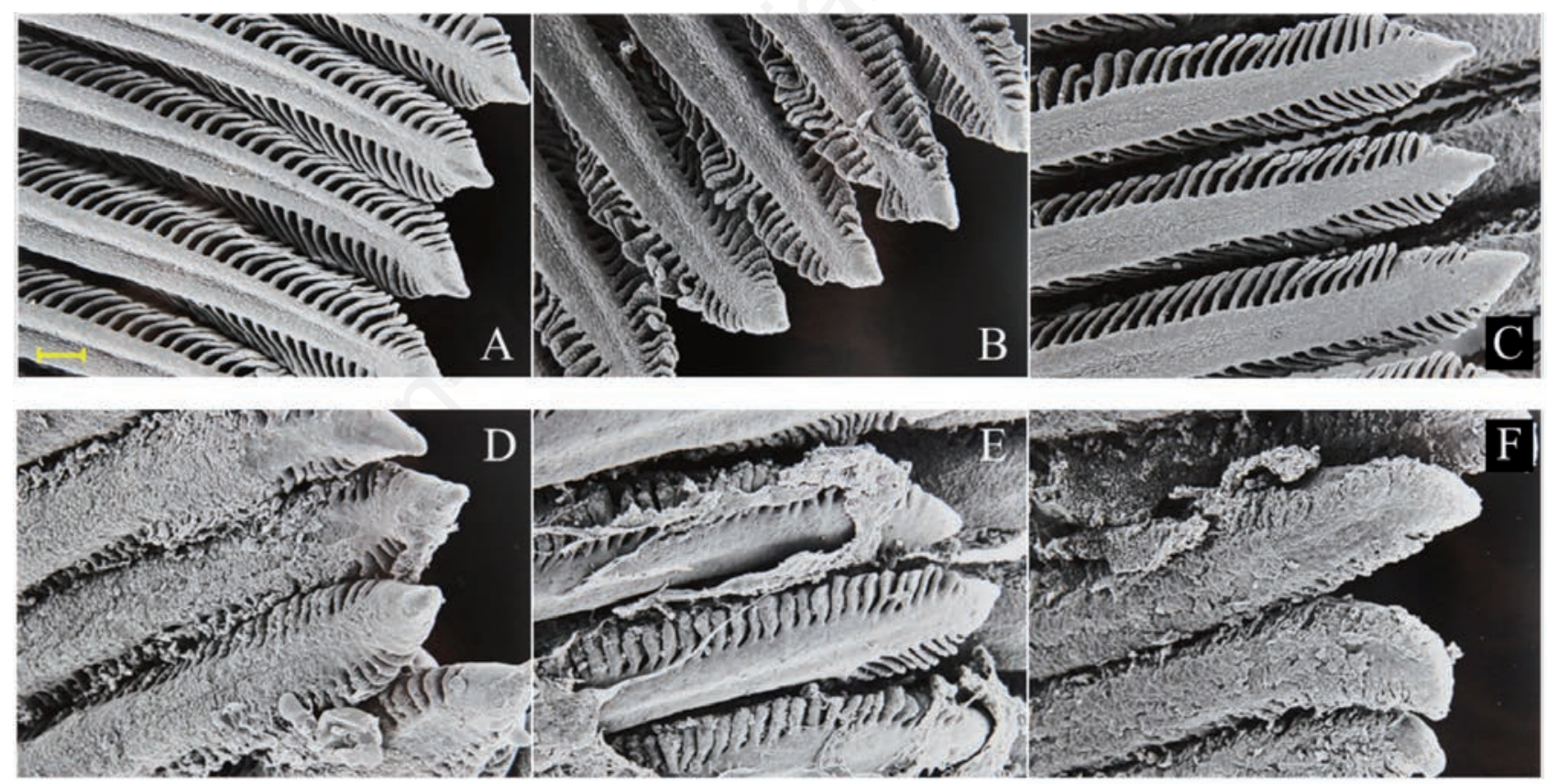

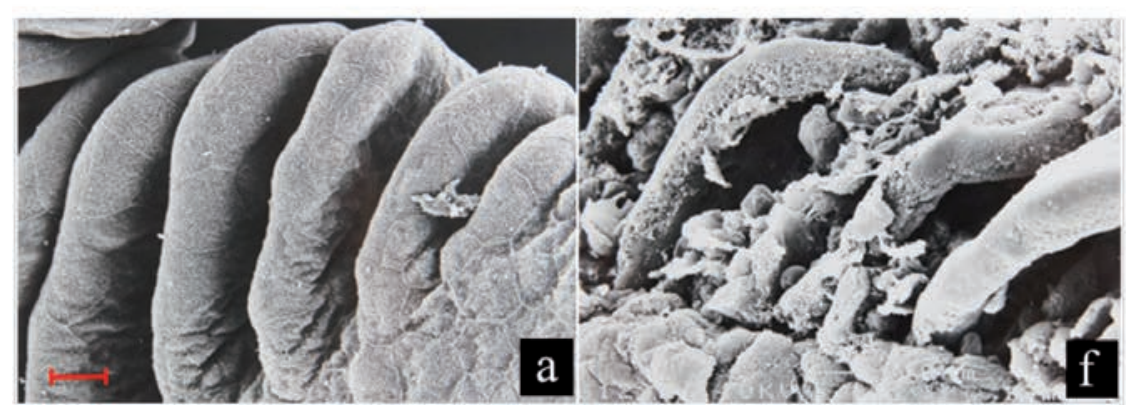

Fig. 5. Scanning electron micrographs of gill filaments (primary lamellae) and secondary lamellae from the apical right side of brown trout. Exposed to untreated department water (A) and to acidic Al-rich medium for 0.5 hours (B), 2 hours (C), 6 hours (D), 8 hours (E) and 11 hours (F) (magnification: $100 \mathrm{X}$, yellow scale bar: $100 \mu \mathrm{m})$. Micrographs denoted with small letters are details (magnification: $1000 \mathrm{X}$, red scale bar: $10 \mu \mathrm{m}$ ) of the gills with the corresponding letter in capital. 
fully recovered and no lamellar fusion was observed, but clubbing was still present to some extent (damage class 1). At the end of the recovery period, after 42 days, it was not possible anymore to differentiate between a gill from the Al-exposed gills and the gills from fish exposed to the Al-poor medium or the untreated water, and all were scored to damage class 0 (Fig. 6C).

All gills from fish exposed to aluminium showed deposition of aluminium on the gill surfaces (blue colour), while fish exposed to the acidic Al-poor medium and the control water showed no such accumulation of aluminium (Fig. 7). The staining was associated with the gill surface and the debris between the lamella, and no staining of the internal gill tissue could be seen, suggesting that aluminium did not cross the gill epithelium or enter the fish. The staining cannot quantify the amount of aluminium deposited, but it was quite evident by visual inspection that it was a correlation between the duration of the aluminium exposure and the amount of staining. Already after a recovery period of 24 hours, no gills from fish exposed to aluminium showed any blue staining, suggesting that aluminium bound to the surfaces of the gills and debris was easily dissolved in the water (Fig.7).

\section{DISCUSSION}

Our results confirm what has been described in several studies before, that aqueous aluminium is toxic to fresh- water fish in general, and to brown trout in particular (Muniz and Leivestad, 1980b; Fivelstad and Leivestad, 1984; Howells et al., 1990; Norrgren et al., 1991; Vuorinen et al., 1993; Rask et al., 1995; Poléo et al., 1997). Furthermore, that the toxic response increases with the duration of the aluminium exposure (Muniz and Leivestad, 1980a; Lydersen et al., 1990; Poléo et al., 1991; Poléo and Muniz, 1993; Poléo and Bjerkely, 2000). Our results also demonstrate that the toxic response to an acutely toxic aluminium challenge is reversible in surviving fish. It has previously been reported that Atlantic salmon (Salmo salar) smolts show the ability to recover from moderate aluminium challenges (Kroglund et al., 2001, 2012; Nilsen et al., 2013). In these studies, however, the smolts were exposed to inorganic monomeric aluminium concentrations between 10 and $40 \mu \mathrm{g} \mathrm{L}^{-1}$, whereas in our study the concentration of this aluminium fraction in the Al-rich medium was $252 \pm 50 \mu \mathrm{g} \mathrm{L}^{-1}$ (Tab. 1). On the other hand, the physiological and morphological disturbances recorded in the present study and the recovery studies on salmon smolts (Kroglund et al., 2012; Nilsen et al., 2013) show comparable changes both during the aluminium exposure and the recovery period.

The present study shows that extensive gill morphology alterations, previously reported to occur in aluminium exposed salmonids (Mueller et al., 1991; Poléo and Bjerkely, 2000), are completely restored following a period in untreated $\mathrm{Al}$-poor water. The indication that the
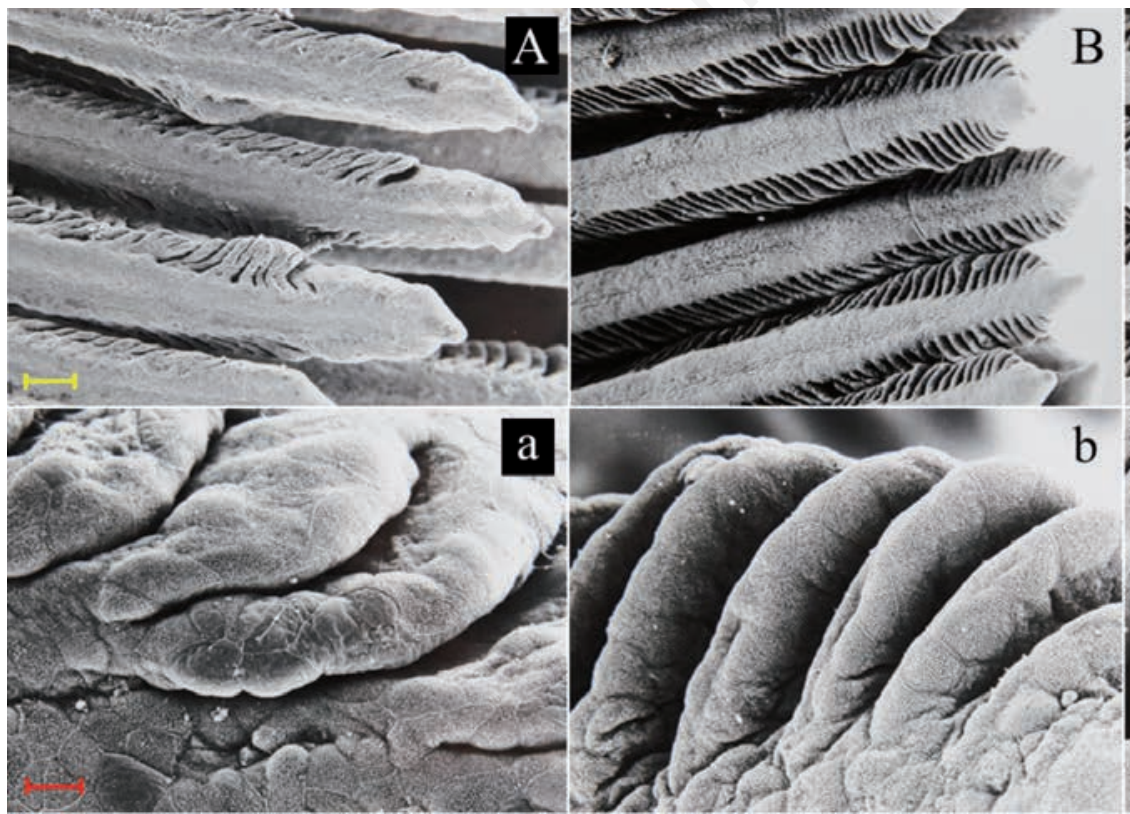

$\mathrm{B}$
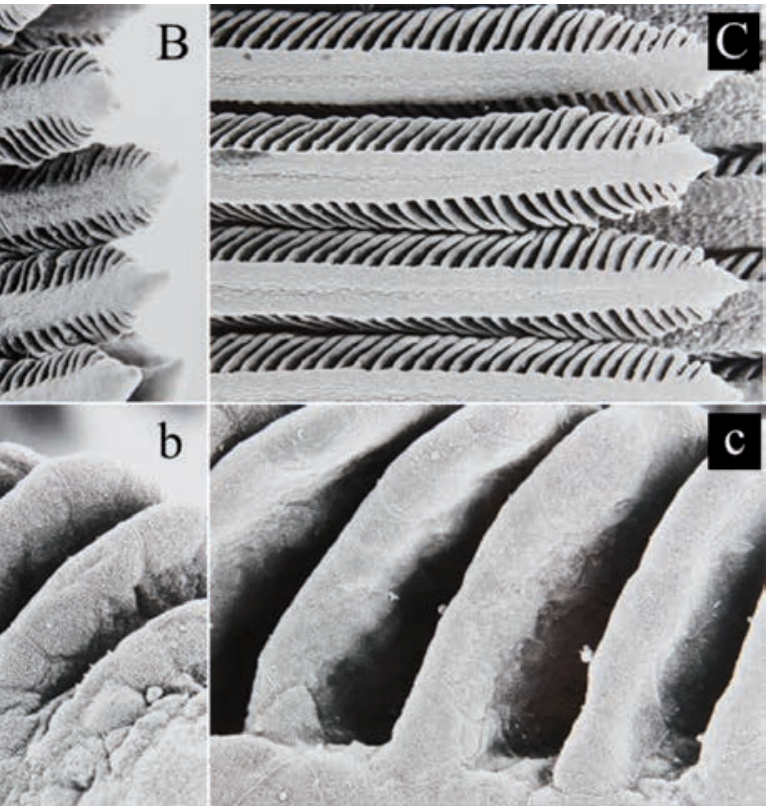

Fig. 6. Scanning electron micrographs of gills after recovery. Upper row (capital letters) filaments (magnification $100 \mathrm{X}$, yellow scale bar: $100 \mu \mathrm{m}$ ). Lower row (small letters) secondary lamellae (magnification $1000 \mathrm{X}$, red scale bar: $10 \mu \mathrm{m}$ ). The micrographs are taken from the right side of brown trout exposed to acidic Al-rich medium for 11 hours, after 1 day of recovery (A), 14 days of recovery (B) and 42 days of recovery $(\mathrm{C})$. 
amount of aluminium deposited on the gills increases with increasing duration of the aluminium exposure is in agreement with (Poléo and Bjerkely, 2000), who measured that the amount of aluminium deposited on the gill surfaces of Arctic char (Salvelinus alpinus) increased with the severity of the aluminium exposure. As for the toxic response, we also demonstrate that aluminium deposited on the gill surfaces disappeared within 1 day after the fish were transferred to the untreated water. Depuration of aluminium has previously been demonstrated to reduce aluminium associated with the gill surfaces quickly, but not completely (Lacroix et al., 1993; Wilkinson and Campbell, 1993; Kroglund et al., 2012; Nilsen et al., 2013). One reason for this could be that aluminium is mainly adsorbed to the gill mucus, especially during the early phase of the aluminium exposure (Wilkinson and Campbell, 1993) and detected as gill associated aluminium when measuring aluminium content in gill samples. The micrographs of solochrome azurin stained gills after 1 day of recovery show that aluminium is no longer attached to the gill epithelium but can still be seen associated to detached mucus or debris particles between gill filaments (Fig. 7D).

Another interesting observation in our study concerning aluminium toxicity is that the brown trout showed effects after an exposure to aluminium for only 30 minutes. The gill micrographs revealed an alteration of the gill surface (damage class 1), and plasma lactate concentration was elevated and significantly higher than in the control (Tab. 4). To our knowledge, a short-term response like this has not been reported before and suggests that acid episodes should be considered in the future evaluation of the importance of climate changes for fish and fish populations in freshwater ecosystems. Since we did not measure plasma lactate in the control fish after only 30 minutes, we cannot rule out that the elevated plasma lactate in the fish exposed for only 30 minutes to aluminium are influenced by handling stress due to the transfer into the exposure chambers. On the other hand, the plasma lactate increased with exposure time in the Al-rich medium, and it should have been opposite if the time since handling was the major effector.

In the present study we exposed the brown trout for a non-steady state aluminium chemistry previously described to be highly toxic to fish (Rosseland et al., 1992; Poléo et al., 1994; Poléo and Bjerkely, 2000; Poléo and Hytterød, 2003), and the morphological and physiological responses we observed corresponded well with those described in these studies. It has been proposed that the primary effect of aluminium under such non-steady state conditions is respiratory disturbances due to aluminium polymerisation and subsequent accumulation on the gill surfaces, leading to ion-regulatory disturbances as secondary effects of hypoxia (Poléo, 1995; Poléo and Bjerkely, 2000; Poléo et al., 2017), which was further supported by the present study. The observation that aluminium was deposited on the gill surfaces of the brown trout in all aluminium exposures, with a corresponding increase in concentration of plasma lactate in the blood even after 30 minutes of exposure, indicate that the aluminium exposed fish became hypoxic (Poléo and

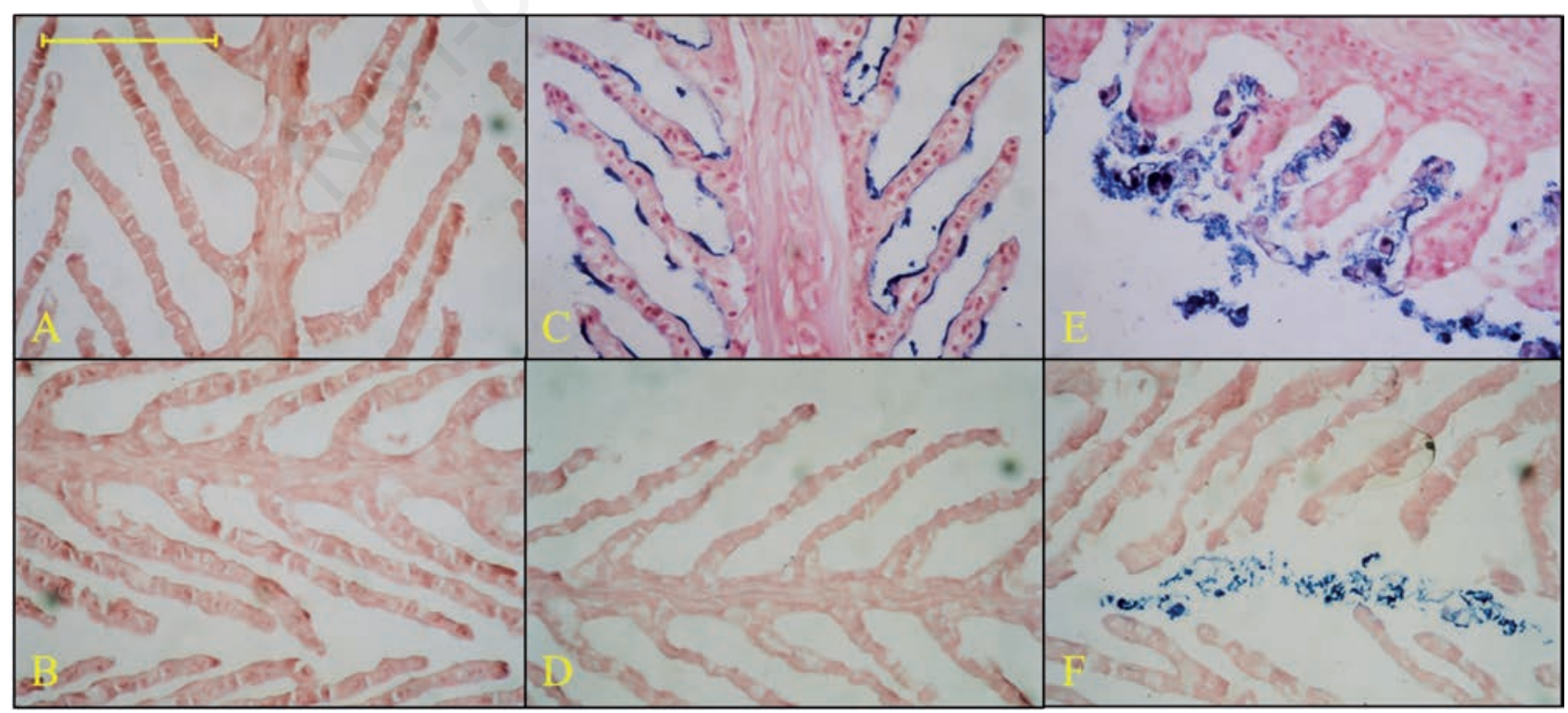

Fig. 7. Light micrographs of acid solochrome azurin stained gills from brown trout. Exposed to untreated department water (A), acidic Al-poor medium (B) and acidic Al-rich medium (C-F): for 0.5 hours (C), for 0.5 hours and 1 day of recovery (D), for 11 hours (E) and for 11 hours and 1 day of recovery (F). Magnification $400 \mathrm{X}$, scale bar: $100 \mu \mathrm{m}$. 
Bjerkely, 2000; Poléo et al., 2017). In addition, gills from aluminium exposed fish showed clubbing and lamellar fusion, i.e., the gill surface area was reduced, and these fish started to ventilate their gills fast with irregular rhythms. The concentration of plasma chloride, on the other hand, was mainly reduced in fish exposed to the Al-rich medium for the longest periods (6-11 hours), and only to a limited extent in fish exposed to this medium for 2 hours, and not in fish exposed for 30 mins. A similar response was observed concerning blood haematocrit, increasing mainly in the fish exposed to the Al-rich medium for between 2 and 11 hours. An increase in blood haematocrit can be caused partly by reduced blood volume or increased red cell volume due to altered osmolality in the blood following plasma ion loss, and partly by release of red blood cells from the spleen to counteract hypoxia (Milligan and Wood, 1982). Since the change in haematocrit did not follow the rapid increase in plasma lactate, we think it is more linked to altered plasma osmolality than to hypoxia. This suggests that the loss of plasma ions, either by increased passive efflux or reduced active uptake, started after the initial hypoxia.

Our results revealed that the recovery of the plasma chloride and blood haematocrit levels took longer time than the recovery of the plasma lactate levels. Plasma lactate concentrations were almost back on normal levels in all the Al-exposure groups already after 1 day of recovery, in correspondence with the disappearing of aluminium from the gill surfaces. The plasma chloride concentration, however, were still significantly reduced in the affected fish after 1 day of recovery, and not fully restored until after 14 days even though no aluminium were evident on the gill surfaces after the first day of the recovery period. Similar delay in recovery of plasma ion levels has been reported in Atlantic salmon smolts (Kroglund et al., 2012; Nilsen et al., 2013). One explanation to this could be oxygen debt in the fish after hypoxia (Hochachka, 1961; Svendsen et al., 2012; Plambech et al., 2013), leading to less ATP from oxidative phosphorylation available for the energy consuming active transport of ions in the gills in order to restore the ion balance after the aluminium exposure.

Another explanation could be that the recovery of the gills on the morphological level or tissue level was sufficient to restore normal gas exchange over the gill epithelium, while the gill epithelium on the cellular and molecular level was still damaged or inhibited in a way that haltered the active uptake of ions (chloride) in order to restore plasma osmolality. The reason for this is probably that oxygen and carbon dioxide are lipid soluble gases crossing the gill epithelium through passive diffusion driven by their partial pressure gradients, while charged water soluble molecules like the blood electrolytes are dependent on active transport by specialised transporter cells and molecules, or channels, to cross the epithelium. It should also be kept in mind that the prolonged reduction in plasma ions during the early phase of the recovery period could be due to increased permeability of the gill epithelium, dependent of a fully recovered gill structure to recover. Furthermore, that the increased passive efflux rate could not be compensated for by influx of ions by active transport, due to either oxygen debt or inhibited transport systems.

It has been shown in several previous studies that a reduced gill surface can be induced by metal exposure (Mueller et al., 1991; Lappivaara et al., 1995; Poléo and Bjerkely, 2000; Schjolden et al., 2007), which also seems to happen in the present study with the gills of aluminium exposed brown trout. In the fish exposed for 11 hours to aluminium, the gills were severely damaged, but showed clear morphological improvements already after 1 day of recovery, followed by a reduction in plasma lactate concentrations from $6.18 \pm 1.38$ to $1.33 \pm 0.20 \mathrm{mmol} \mathrm{L}^{-1}$. Accordingly, it has been reported that arterial oxygen tension recovered fully in rainbow trout (Oncorhynchus mykiss) exposed to waterborne zinc after 48 hours in clean water, despite the fact that the gill morphology was only partly recovered (Lappivaara et al., 1995). The clubbing and lamellar fusion seen in aluminium exposed fish gills documented in the present and earlier studies (Mueller et al., 1991; Poléo and Bjerkely, 2000) is probably caused by cell proliferation in the interlamellar spaces, as suggested in a review (Nilsson et al., 2012). Ion transporting ionocytes, referred to as chloride cells in older literature, are most abundant in the interlamellar regions at the base of the lamellae (Perry and Laurent, 1993; Evans et al., 2005), and it might be that their function was inhibited by the cell mass still covering them in the not fully recovered gills. On the other hand, it has been shown that the interlamellar cell mass (ILCM) filling the interlamellar spaces in goldfish (Carassius auratus) gills consists mainly of undifferentiated cells, but also mitochondria rich ionocytes (Mitrovic et al., 2009). Furthermore, these ionocytes were located at the outer part of the ILCM facing the water, and that these ionocytes migrated with the shrinking ILCM in goldfish gills during hypoxia, keeping their position towards the water (Mitrovic et al., 2009). It remains to be investigated, however, if the same is happening when ILCM is shrinking during recovery in aluminium exposed brown trout or salmonid gills.

The somewhat postponed recovery of the ion regulation compared to the respiration, could simply be that the ionocytes are damaged by aluminium directly or indirectly by hypoxia, and that it takes somewhat longer time for this to recover due to repairment or replacement of the damaged cells. It has been reported a reduced activity of carbonic anhydrase and Na-K-ATPase activity in rainbow trout and Atlantic salmon exposed to aluminium (Staurnes 
et al., 1984), but the study do not confirm if the reduced enzyme activity was due to a direct effect on the cell or molecular level, or an indirect effect caused by hypoxia and less ATP available for the energy consuming active transport in the ionocytes.

\section{CONCLUSIONS}

The present study confirms that a toxic response in surviving brown trout, exposed to aluminium in a similar way that is likely to take place in nature during acidic episodes, is reversible. Both physiological and morphological damages was almost completely resituated within two weeks of recovery. The mortality of fish during the first 24 hours after the termination of the aluminium exposures, suggests that this period is most critical for the fish recovery. This is supported by the fact that no fish died during the remaining 41 days of the recovery period. Our observations indicate that there must be a threshold - a "point of no return" - for the development of the toxic response in the fish during aluminium exposure that can be reversed. It remains, however, to be investigated what that threshold could be, both morphologically and physiologically. Moreover, in light of climate change with increased frequency and severity of rainy storms, it also remains to be determined what is the critical load of aluminium in terms of concentrations, and durations and frequencies of episodes, for the survival of fish populations in areas affected by chronic acidification in the past.

Our study gives support to the hypothesis that hypoxia is the primary effect of acute aluminium toxicity in fish and demonstrates that the hypoxic response during an episodic aluminium exposure can be recovered already 1 day after the exposure was terminated. This study also confirm that aluminium deposited at the gill surfaces during aluminium exposure disappear within the first 24 hours after fish are moved to untreated water. Possible ion regulatory and osmotic disturbances, measured as elevated blood haematocrit and reduced plasma chloride, took longer time to recover. This could be due to either, or a combination of, oxygen debt from the hypoxia, damage on ionocytes and transport molecules, and increased permeability of the altered gill epithelium. Our results indicate that the recovery period for brown trout exposed to an acutely toxic aluminium challenge of $600 \mu \mathrm{g} \mathrm{L}^{-1}$ lasts for no longer that 14 days, but since we did not measure the physiological status of the fish between day 1 and 14 during the recovery period, we are not able to show exactly how long time the brown trout need to fully recover. The results, however, indicate that the effects of a moderate exposure to $\mathrm{Al}$-rich water, between 30 minutes and 2 hours, are fully recovered already after 1 day in untreated water. Finally, the last question to be answered is if the brown trout, or fish species in general, must fully recover the ion regulatory and osmotic disturbances in order to survive repetitive episodes with shorter intervals than 14 days.

\section{ACKNOWLEDGEMENTS}

The authors wish to thank Jannike G.B. Jensen and Bente Tornsjø for conducting the analyses of major water ions. We also wish to thank Kine Bakke for digitalising the light and electron microscopy images. Finally, we thank two anonymous referees for helping us improve the quality of our manuscript.

\section{REFERENCES}

Alexander AC, Chambers PA, Jeffries DS, 2017. Episodic acidification of 5 rivers in Canada's oil sands during snowmelt: A 25-year record. Sci. Tot. Environ. 599-600:739-749.

Andersen DO, 2006. Labile aluminium chemistry downstream a limestone treated lake and an acid tributary: effects of warm winters and extreme rainstorms. Sci. Tot. Environ. 366:739-748.

Barnes RB, 1975. The determination of specific forms of aluminum in natural water. Chem. Geol. 15:177-191.

Cronan CS, Schofield CL, 1979. Aluminium leaching response to acid precipitation: effects on high-elevation watersheds in the northeast. Science 204:304-306.

Denton J, Freemont AJ, Ball J, 1984. Detection and distribution of aluminium in bone. J. Clin. Pathol. 37:136-142.

Driscoll CT, 1984. A procedure for the fractionation of aqueous aluminum in dilute acidic waters. Intern. J. Environ. Anal. Chem. 16:267-283.

Driscoll CT, Baker JP, Bisogni JJ, Schofield CL, 1980. Effects of aluminum speciation on fish in dilute acidified waters. Nature 284:161-164.

Enge E, Auestad BH, Hesthagen T, 2016. Temporary increase in sea salt deposition accelerates recovery of brown trout (Salmo trutta) populations in very dilute and acidified mountain lakes. Water Air Soil Pollut. 227:208.

Evans DH, Piermarini PM, Choe KP, 2005. The multifunctional fish gill: Dominant site of gas exchange, osmoregulation, acid-base regulation, and excretion of nitrogenous waste. Physiol. Rev. 85:97-177.

Fakhraei H, Driscoll CT, 2015. Proton and aluminium binding properties of organic acids in surface waters of the Northeastern U.S. Environ. Sci. Technol. 49:2939-2947.

Fivelstad S, Leivestad H, 1984. Aluminium toxicity to Atlantic salmon (Salmo salar L.) and brown trout (Salmo trutta L.): mortality and physiological response. Rep. Inst. Freshw. Res. Drottningholm 61:69-77.

Garmo ØA, Skjelkvåle BL, de Wit HA, Colombo L, Curtis C, Fölster J, Hoffmann A, Hruska J, Høgåsen T, Jeffries DS, Keller WB, Kram P, Majer V, Monteith DT, Paterson AM, Rogora M, Rzychon D, Steingruber S, Stoddard JL, Vuorenmaa J, Worsztynowicz A, 2014. Trends in surface water chemistry in acidified areas in Europe and North America from 1990 to 2008. Water Air Soil Pollut. 225:1880.

Gensemer RW, Playle RC, 1999. The bioavailability and toxicity 
of aluminium in aquatic environments. Crit. Rev. Environ. Sci. Technol. 29:315-450.

Harriman R, Morrison BRS, 1981. Forestry, fisheries and acid rain in Scotland. Scot. Forest. 35:89-95.

Harvey HH, 1975. Fish populations in a large group of acidstressed lakes. Verh. Int. Ver. Theor. Angew. Limnol. 19:2406-2417.

Harwood JE, 1969. The use of an ion-selective electrode for routine fluoride analysis on water samples. Water Res. 3:273-280.

Hem DJ, Robertson CE. 1976. Form and stability of aluminum hydroxide complexes in dilute solution. Geol Survey Watersuppl Paper 1827-A, U.S. Government Printing Office, Washington DC.

Hesthagen T, Fjellheim A, Schartau AK, Wright RF, Saksgård $\mathrm{R}$, Rosseland BO, 2011. Chemical and biological recovery of Lake Saudlandsvatn, a highly acidified lake in southernmost Norway, in response to decreased acid deposition. Sci. Tot. Environ. 409:2908-2916.

Hesthagen T, Fiske P, Saksgård R, 2016. Recovery of young brown trout (Salmo trutta) in acidified streams: What are the critical values for acid-neutralizing capacity? Atm. Environ. 146:236-244.

Hindar A, Henriksen A, Tørseth K, Semb A, 1994. Acid water and fish death. Nature 372 327-328.

Hochachka PW, 1961. The effect of physical training on oxygen debt and glycogen reserves in trout. Can. J. Zool. 39:767-776.

Howells G, Dalziel TRK, Reader JP, Solbe JF, 1990. EIFAC water quality criteria for European freshwater fish: report on aluminium. Chem. Ecol. 4:117-173.

Howells G, Dalziel TRK, Reader JP, Solbe JF, 1994. Aluminium and freshwater fish water quality criteria, p. 55-115. In: G. Howells (ed), Water quality for freshwater fish. Gordon and Breach Sci. Publ., London.

Johannessen M, Skartveit A, Wright RF, 1980. Streamwater chemistry before, during and after snowmelt, p. 224-225. In: D. Drabløs and A. Tollan (eds), Ecological impact of acid precipitation. SNSF project, Ås, Norway.

Kowalik RA, Ormerod SJ, 2006. Intensive sampling and transplantation experiments reveal continued effects of episodic acidification on sensitive stream invertebrates. Freshwater Biol. 51:180-191.

Kroglund F, Teien HC, Rosseland BO, Salbu B, Lucassen ECHET, 2001. Water quality dependent recovery from aluminium stress in Atlantic salmon smolt. Water Air Soil Pollut. 130:911-916.

Kroglund F, Finstad B, Pettersen K, Teien HC, Salbu B, Rosseland BO, Nilsen TO, Stefansson S, Ebbesson LOE, Nilsen R, Bjørn PA, Kristensen T, 2012. Recovery of Atlantic salmon smolts following aluminum exposure defined by changes in blood physiology and seawater tolerance. Aquaculture 362-363:232-240.

Lacroix GL, Peterson RH, Belfry CS, Martin-Robichauda DJ, 1993. Aluminum dynamics on gills of Atlantic salmon fry in the presence of citrate and effects on integrity of gill structure. Aquat. Toxicol. 27:373-401.

Lappivaara J, Nikinmaa M, Tuurala H, 1995. Arterial oxygen tension and the structure of the secondary lamellae of the gills in rainbow trout (Oncorhynchus mykiss) after acute exposure to zinc and during recovery. Aquat. Toxicol. 32:321-331.

Laudon H, Bishop KH, 1999. Quantifying sources of acid neutralisation capacity depression during spring flood episodes in northern Sweden. Environ. Pollut. 105:427-435.

Lawrence GB, David MB, Lovett GM, Murdoch PS, Burns DA, Stoddard JL, Baldigo BP, Porter JH, Thompson AW, 1999. Soil calcium status and the response of stream chemistry to changing acidic deposition rates. Ecol. Appl. 9:1059-1072.

Likens GE, Wright RF, Galloway JN, Butler TJ, 1979. Acid Rain. Sci. Am. 241:43-51.

Lydersen E, Poléo ABS, Muniz IP, Salbu B, Bjørnstad HE, 1990. The effects of naturally occurring high and low molecular weight inorganic and organic species on the yolk-sack larvae of Atlantic salmon (Salmo salar L.) exposed to acidic aluminium-rich lake water. Aquat. Toxicol. 18:219-230.

Lydersen E, Poléo ABS, Nandrup Pettersen M, Riise G, Salbu B, Kroglund F, Rosseland BO, 1994. The importance of in situ measurements to relate toxicity and chemistry in dynamic aluminium freshwater systems. J. Ecol. Chem. 3:357-365.

McWilliams PG, 1980. Acclimation to an acid medium in the brown trout Salmo trutta. J. Exp. Biol. 88:269-280.

Milligan CL, Wood CM, 1982. Disturbances in haematology, fluid volume distribution and circulatory function associated with low environmental $\mathrm{pH}$ in the rainbow trout, Salmo gairdneri. J. Exp. Biol. 99:397-415.

Mitrovic D, Dymowska A, Nilsson GE, Perry SF, 2009. Physiological consequences of gill remodelling in goldfish (Carassius auratus) during exposure to long-term hypoxia. Am. J. Physiol. Regul. Integr. Comp. Physiol. 297:R224-R234.

Mueller ME, Sanchez DA, Bergman HL, McDonald DG, Rhem RG, Wood CM, 1991. Nature and time course of acclimation to aluminium in juvenile brook trout (Salvelinus fontinalis). II. Gill histology. Can. J. Fish. Aquat. Sci. 48:2016-2027.

Muniz IP, 1984. The effects of acidification on Scandinavian freshwater fish fauna. Phil. Trans. Royal Soc. London 305: 517-528.

Muniz IP, Leivestad H, 1980a. Acidification effects on freshwater fish, p. 84-92. In: D. Drabløs and A. Tollan (eds.), Ecological impact of acid precipitation. SNSF project, Ås, Norway.

Muniz IP, Leivestad H, 1980b. Toxic effects of aluminium on the brown trout, Salmo trutta L., p. 320-321. In: D. Drabløs and A. Tollan (eds.), Ecological impact of acid precipitation. SNSF project, Ås, Norway.

Neville CM, 1985. Physiological response of juvenile rainbow trout, Salmo gairdneri, to acid and aluminum - Prediction of field responses from laboratory data. Can. J. Fish. Aquat. Sci. 42:2004-2019.

Nilsen TO, Ebbesson LOE, Handeland SO, Kroglund F, Finstad B, Angotzi AR, Stefansson SO, 2013. Atlantic salmon (Salmo salar L.) smolts require more than two weeks to recover from acidic water and aluminium exposure. Aquat. Toxicol. 142-142:33-44.

Nilsson GE, Dymowska A, Stecyk JAW, 2012. New insights into the plasticity of gill structure. Resp. Physiol. Neurobiol. 184:214-222.

Norrgren L, Wicklund GA, Malmborg O, 1991. Accumulation and effects of aluminium in the minnow (Phoxinus phoxinus L.) at different $\mathrm{pH}$ levels. J. Fish Biol. 39:833-847.

Perry SF, Laurent P, 1993. Environmental effects on fish gill structure and function, p. 231-264. In: J.C. Rankin and F.B. Jensen (eds.), Fish ecophysiology. Chapman and Hall, London.

Plambech M, Van Deurs M, Steffensen JF, Tirsgaard B, Behrens JW, 2013. Excess post-hypoxic oxygen consumption in Atlantic cod Gadus morhua. J. Fish. Biol. 83:396-403. 
Playle RC, Goss GG, Wood CM, 1989. Physiological disturbances in rainbow trout (Salmo gairdneri) during acid and aluminum exposure in soft water of two calcium concentrations. Can. J. Zool. 67:314-324.

Poléo ABS, 1995. Aluminium polymerization - a mechanism of acute toxicity of aqueous aluminium to fish. Aquat. Toxicol. 31:347-356.

Poléo ABS, Bjerkely F, 2000. Effect of unstable aluminium chemistry on Arctic char (Salvelinus alpinus). Can. J. Fisher. Aquat. Sci. 57:1423-1433.

Poléo ABS, Hytterød S, 2003. The effect of aluminium in Atlantic salmon (Salmo salar) with special emphasis on alkiline water. J. Inorg. Chem. 97:89-96.

Poléo ABS, Lydersen E, Muniz IP, 1991. The influence of temperature on aqueous aluminium chemistry and survival of Atlantic salmon (Salmo salar L.) fingerlings. Aquat. Toxicol. 21:267-278.

Poléo ABS, Lydersen E, Rosseland BO, Kroglund F, Salbu B, Vogt RD, Kvellestad A, 1994. Increased mortality of fish due to changing Al-chemistry of mixing zones between limed streams and acidic tributaries. Water Air Soil Pollut. 75:339-351.

Poléo ABS, Muniz IP, 1993. The effect of aluminium in soft water at low $\mathrm{pH}$ and different temperatures on mortality, ventilation frequency and water balance in smoltifying Antlantic salmon (Salmo salar L.). Environ. Biol. Fish. 36:193-203.

Poléo ABS, Øxnevad SA, Østbye K, Andersen RA, Oughton DH, Vøllestad LA, 1995. Survival of crucian carp, Carassius carassius, exposed to a high low-molecular weight inorganic aluminium challenge. Aquat. Sci. 57:350-359.

Poléo ABS, Østbye K, Øxnevad SA, Andersen RA, Heibo E, Vøllestad LA, 1997. Toxicity of acid aluminium-rich water to seven freshwater fish species: a comparative laboratory study. Environ. Pollut. 96: 129-139.

Poléo ABS, Schjolden J, Sørensen J, Nilsson GE, 2017. The high tolerance to aluminium in crucian carp (Carassius carassius) is associated with its ability to avoid hypoxia. PLoS One 12:e0179519.

Pye MC, Vaughan IP, Ormerod SJ, 2012. Episodic acidification affects the breakdown and invertebrate colonisation of oak litter. Freswater Biol. 57:2318-2329.

Rask M, Mannio J, Forsius M, Posch M, Vuorinen PJ, 1995. How many fish populations in Finland are affected by acid precipitation? Environ. Biol. Fish. 42:51-63.

Rosseland BO, Blakar IA, Bulger A, Kroglund F, Kvellestad A, Lydersen E, Oughton DH, Salbu B, Staurnes M, Vogt R, 1992. The mixing zone between limed and acidic river waters: Complex aluminium chemistry and extreme toxicity for salmonids. Environ. Pollut. 78:3-8.

Schjolden J, Sørensen J, Nilsson GE, Poléo ABS, 2007. The toxicity of copper to crucian carp (Carassius carassius) in soft water. Sci. Total Environ. 384:239-251.

Schofield CL, 1976. Acid precipitation. Effects on fish. Ambio 5:5-6.

Seip HM, Andersen DO, Christophersen N, Sullivan TJ, Vogt RD, 1989. Variations in concentrations of aqueous aluminium and other chemical species during hydrological episodes at Birkenes, southernmost Norway. J. Hydrol. 108:387-405.

Serrano I, Buffam I, Palm D, Brannas E, Laudon H, 2008. Thresholds for survival of brown trout during the spring flood acid pulse in streams high in dissolved or- ganic carbon. Trans. Am. Fish. Soc. 137:1363-1377.

Skartveit A, Gjessing YT, 1979. Chemical budgets and chemical quality of snow and runoff during spring snowmelt. Nordic Hydrol. 10:141-154.

Skjelkvåle BL, Wright RF, Henriksen A, 1998. Norwegian lakes show widespread recovery from acidification: results of national surveys of lake water chemistry 1986-1997. Hydrol. Earth Syst. Sci. 2:555-562.

Skjelkvåle BL, Wilander A, Hindar A, Borg H, 2007. Large scale patterns of chemical recovery in lakes in Norway and Sweden: importance of sea salt episodes and changes in dissolved organic carbon. Appl. Geochem. 22:1174-1180.

Sparling DW, Lowe TP, 1996. Environmental hazards of aluminum to plants, invertebrates, fish, and wildlife. Rev. Environ. Contam. Toxicol. 145:1-127.

Staurnes M, Sigholt T, Reite OB, 1984. Reduced carbonic anhydrase and Na-K-ATPase activity in gills of salmonids exposed to aluminium-containing acid water. Experientia 40:226-227.

Stoddard JL, Jeffries DS, Lükewille A, Clair TA, Dillon PJ, Driscoll CT, Forsius M, Johannessen M, Kahl JS, Kellogg JH, Kemp J, Mannio J, Monteith DT, Murdoch PS, Patrick S, Rebsdorf A, Skjelkvåle BL, Stainton MP, Traaen T, van Dam H, Webster KE, Wieting J, Wilander A, 1999. Regional trends in aquatic recovery from acidification in North America and Europe. Nature 401:575-578.

Svendsen JC, Steffensen JF, Aarestrup K, Frisk M, Etzerodt A, Jyde M, 2012. Excess posthypoxic oxygen consumption in rainbow trout (Oncorhynchus mykiss): recovery in normoxia and hypoxia. Can. J. Zool. 90:1-11.

Vuorinen M, Vuorinen PJ, Peuranen S, 1993. Lethal and sublethal threshold values of aluminium and acidity to pike (Esox Lucius), whitefish (Coregonus lavaretus pallasi), pike perch (Stizostedion lucioperca) and roach (Rutilus rutilus) yolk-sac fry. Sci. Tot. Environ. 134:s953-967.

Weatherley NS, Rutt GP, Thomas P, Ormerod SJ, 1991. Liming acid streams: aluminium toxicity to fish in mixing zones. Water Air Soil Pollut. 55:345-353.

Wellington BI, Driscoll CT, 2004. The episodic acidification of a stream with elevated concentrations of dissolved organic carbon. Hydrol. Processes 18:2663-2680.

Wigington PJ, Davies TD, Tranter M, Eshleman KN, 1992. Comparison of episodic acidification in Canada, Europe and the United States. Environ. Pollut. 78:29-35.

Wigington PJ, DeWalle DR, Murdoch PS, Kretser WA, Simonin HA, Van Sickle J, Baker JP, 1996. Episodic acidification of small streams in the northeastern United States: ionic controls of episodes. Ecol. Appl. 6:389-407.

Wilkinson KJ, Campbell PGC, 1993. Aluminum bioconcentration at the gill surface of juvenile Atlantic salmon in acidic media. Environ. Toxicol. Chem. 12:2083-2095.

Witters HE, 1986. Acute acid exposure of rainbow trout, Salmo gairdneri Richardson: effects of aluminium and calcium on ion balance and haematology. Aquat. Toxicol. 8:197-210.

Wright RF, 2008. The decreasing importance of acidification episodes with recovery from acidification: an analysis of the 30 -year record from Birkenes, Norway. Hydrol. Earth Syst. Sci. 12:353-362.

Wright RF, Snekvik E, 1978. Acid precipitation: chemistry and fish population in 700 lakes in southernmost Norway. Verh. Intern. Ver. Theor. Angew. Limnol. 20:765-775. 